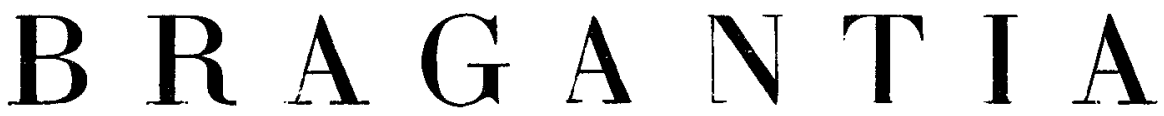

Boletim Científico do Instituto Agronômico do Estado de S. Paulo

Vol. 29

Campinas, outubro de 1970

N. ${ }^{\circ} 31$

\title{
AVALIAÇÃO DAS PERDAS CAUSADAS POR VÍRUS NA PRODUÇÃO DA BATATA
}

\section{I - VIRUS DO ENROLAMENTO DA FÔLHA ( $\left.{ }^{1}\right)$}

F. P. Cupertino e A. S. Costa $\left({ }^{2}\right)$, engenheiros-agrônomos, Seção de Virologia, Instituto Agronômico

\section{SINOPSE}

A comparação entre as produções de 50 pares de plantas sadias e afetadas, de nove variedades de batata, mostra que a redução na produção causada pela infecção secundária do vírus do enrolamento da fôlha foi, em média, de $60,8 \%$ no pêso total dos tubérculos produzidos e de $75,5 \%$ no pêso dos tubérculos do tipo graúdo ("especial" mais "primeira"). As perdas na produção total variaram de $44,6 \%$ (variedade Patrones) a $73,4 \%$ (variedade Aquila), e na de tubérculos graúdos, de $49,8 \%$ (Delta A) a $86,0 \%$ (Gunda).

\section{1 - INTRODUÇÃO}

As moléstias de vírus têm grande importância na cultura da batata (Solanum tuberosum L.) pelo papel que desempenham na degenerescência da batata-semente e pela redução que ocasionam na produção.

A presente linha de investigação visou avaliar as perdas causadas na produção da batata por moléstias de vírus perpetuảveis através dos tubérculos e fornecer elementos para o estabelecimento de critério acêrca do nível de vlrus a ser tolerado na batata-semente certificada.

(1) Trabalho realizado com ajuda financeira da Fundação de Amparo à Pesquisa do Estado de São Paulo (Agron. 66/146) e apresentado na VIII Reunião da Sociedade de Olericultura do Brasil, em Curitiba (PR), em julho de 1968. Recebido para publicação em 2 de junho de 1970.

$\left({ }^{2}\right)$ Bolsistas do Conselho Nacional de Pesquisas. 
Presentemente, o enrolamento da fôlha é a moléstia de vírus de maior disseminação na cultura da batata no Estado de São Paulo, apresentando sérios embaraços ao estabelecimento de um programa de produção de batata-semente certificada em bases permanentes. A incidência dessa moléstia em batatais pode atingir até $100 \%$, conforme a procedência e o número de multiplicações da batata-semente usada.

Os sintomas apresentados por plantas de batata que contraem o vírus do enrolamento durante o ciclo vegetativo são os chamados de infecção primária. Todavia, na maioria dos casos as plantas assim afetadas terminam o ciclo sem apresentar sintomas (1). Como consequiência, as perdas causadas pelo enrolamento primário são de menor importância. Os sintomas apresentados por plantas originárias de tubérculos infetados pelo virus do enrolamento são chamados os de infecção secundária. Tais plantas apresentam-se com enrolamento e amarelo sectorial, que aparecem primeiro nas fôlhas mais velhas, menor crescimento, fôlhas quebradiças e com os bordos arroxeados em algumas variedades (1), sofrendo em decorrência de tais sintomas maior perda na produção.

A determinação das perdas ocasionadas na produção da batata pela infecção secundảria do vírus do enrolamento da fôlha é importante para o estudo da degenerescência da batata-semente, permitindo a avaliação dos prejuízos sofridos pelo lavrador ao usar tubércilos de baixo teor de sanidade para. plantio.

\section{2 - MATERIAIS E MÉTODOS}

Para a obtenção dos presentes dados, usaram-se pares de plantas sadias e afetadas, com sintomas de enrolamento secundário, marcadas em culturas destinadas à produção de batata para consumo de mesa.

Das 9 variedades de batata utilizadas, 8 delas foram cultivada's em solo orgânico da região do Vale do Paraíba $\left({ }^{3}\right)$, sendo 6 em lavouras do município de Taubaté (Capella, Delta A, Gunda,

$\left({ }^{3}\right)$ Os autores agradecem aos engenheiros-agrônomos Dr. Olavo J. Boock, do Instituto Agronômico de Campinas, Jasson Botelho, da DIRA do Vale do Parába, e Rubens Machado, da DIRA de Campinas, pela colaboração prestada, e aos Srs. Delmo Montese, Demo Canavese e Sérgio Valério, de Taubaté, e Jaime de Melo, de Águas da Prata, por terem permitido a realizaçáo do presente trabalho em suas lavouras. 
Isola, Oda e Stamm-52) e 2 em lavouras de Pindamonhangaba (Aquila e Patrones), e uma cultivada em Latossolo Vermelho Amarelo-Orto, no município de Águas da Prata (Olímpia).

Marcaram-se 50 pares de plantas (sadia e afetada) para cada uma das variedades, em cada cultura, com estacas de bambu prèviamente preparadas, em diferentes côres. Na marcaçāo dos pares de plantas sadias e afetadas pelo enrolamento secundário, a escolha da sadia recaiu sempre na segunda planta adjacente à afetada.

As determinações feitas constaram de pesagem e classificação dos tubérculos, planta por planta, nos tipos comerciais de "especial" (acima de $50 \mathrm{~mm}$ ), "primeira" (de 40 a $50 \mathrm{~mm}$ ), "segunda" (de 33 a $40 \mathrm{~mm}$ ), "terceira" (de 28 a $33 \mathrm{~mm}$ ) e "quarta" (abaixo de $28 \mathrm{~mm}$ ). Dessa forma foram obtidos número e pêso da produção por tipo.

Os tratos culturais e fitossanitários dispensados às plantas sadias e afetadas foram os mesmos até a colheita, que se deu após a seca completa das fôlhas e hastes das plantas produtoras.

\section{3 - RESULTADOS}

No quadro 1 se vê a produção de 50 plantas sadias e de 50 afetadas pelo enrolamento secundário, de cada variedade, em pêso e número de tubérculos, distribuídos em tipos comerciais. Ém 3 variedades (Aquila, Olímpia e Patrones) das 9 ensaiadas, não foram tomados os pesos dos tubérculos por tipo, mas apenas o número dêles. Os referidos dados representam a soma das produções tomadas individualmente, após a verificação de que as diferenças entre as produçōes das plantas sadias e das afetadas permaneciam constantes. Os dados não podem ser analisados como um ensaio de variedades, uma vez que as determinações foram feitas em lavouras conduzidas em diferentes épocas e tipos de solo. As comparações devem ser feitas entre plantas sadias e afetadas de mesma variedade.

\section{1 - REDUÇÃO NA PRODUÇÃO DA PLANTA AFETADA EM PÊSO E NÚMERO DE TUBÉRCULOS}

No quadro 2 se encontra o resultado da comparação entre as produções das plantas sadias e afetadas pelo enrolamento secundário, de cada variedade, em base percentual, em pêso e número de tubérculos. 


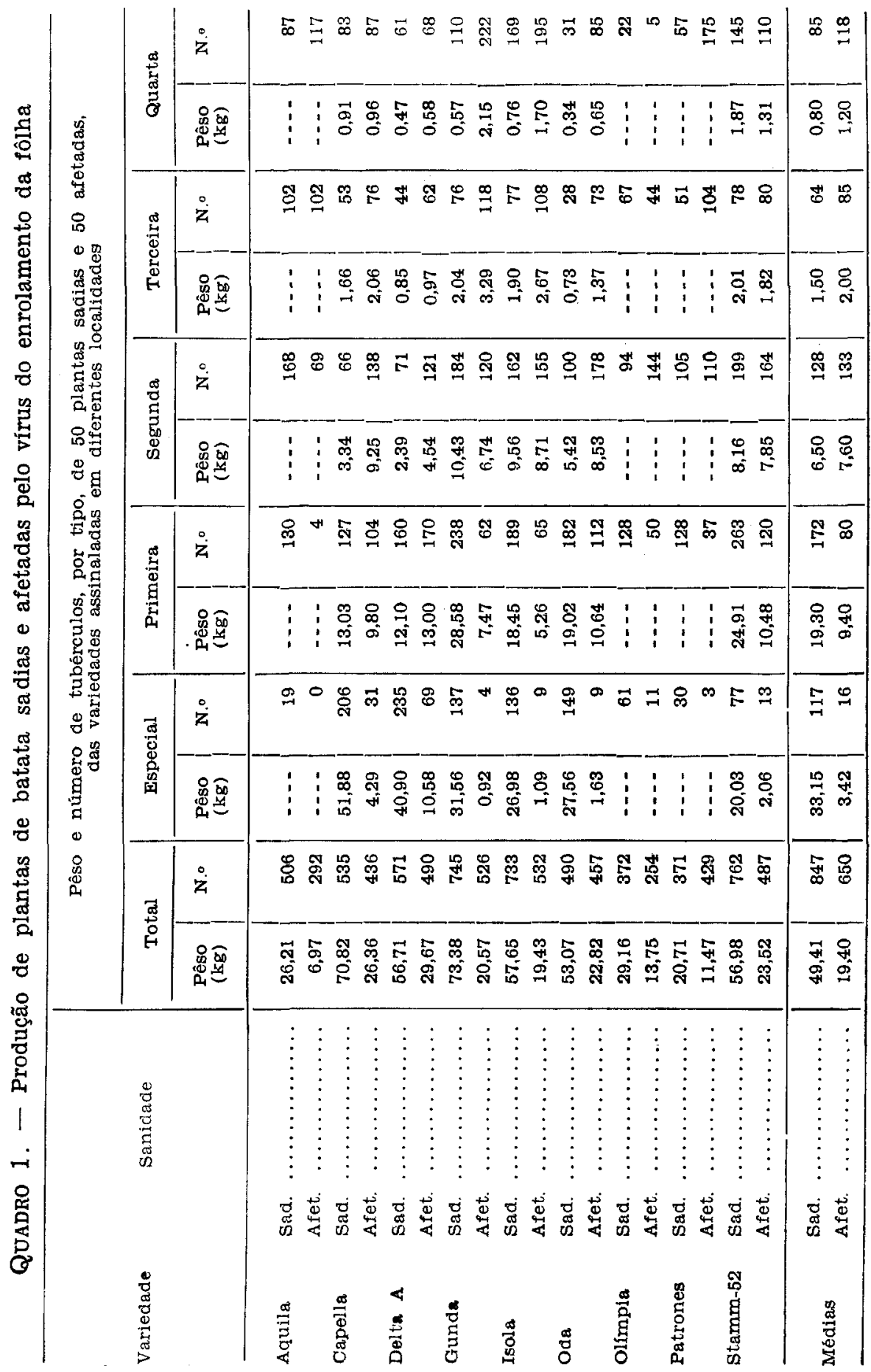




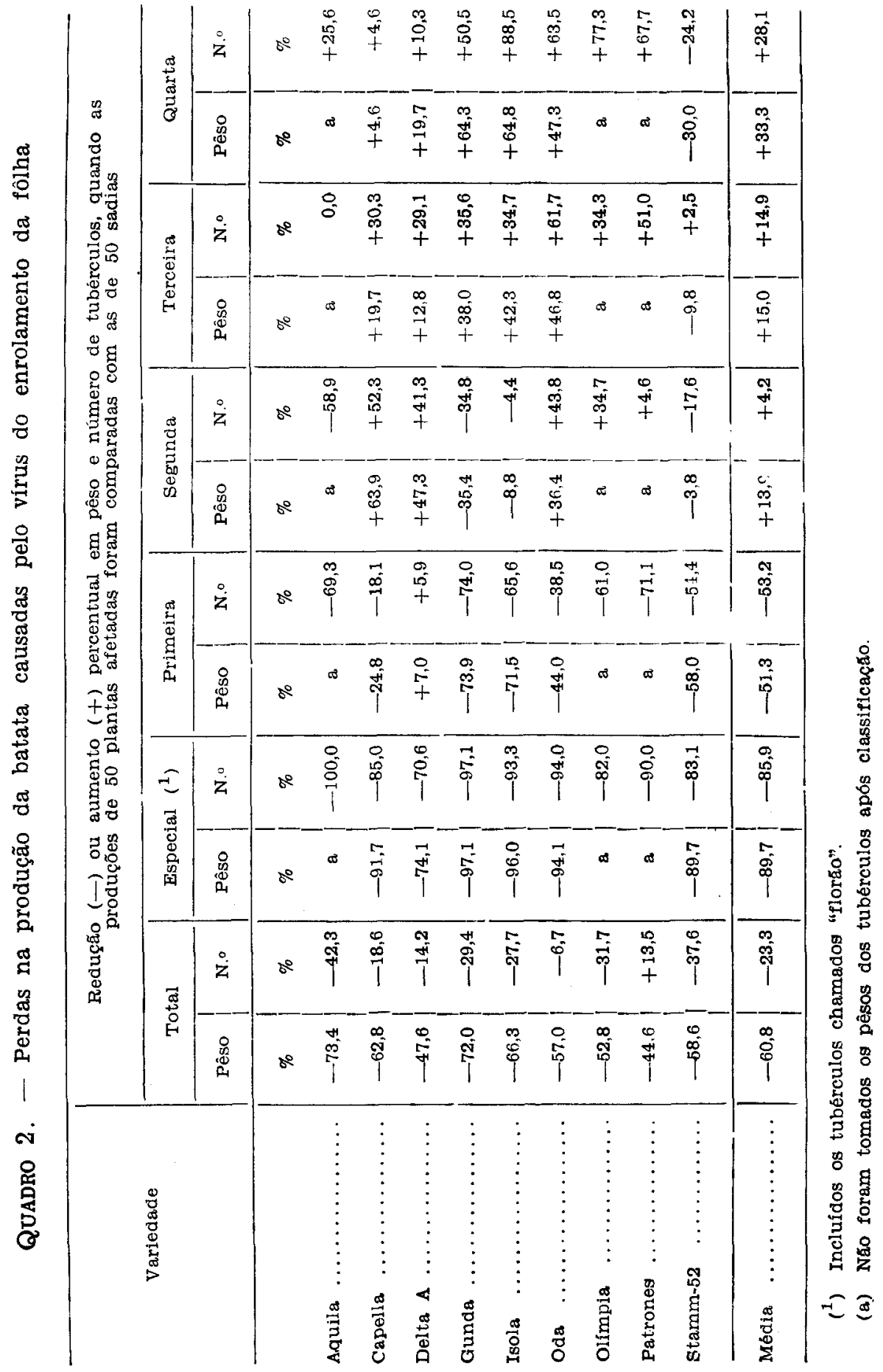


Vê-se que tôdas as variedades sofreram redução no pêso da produção, sendo de $73,4 \%$ na Aquila, $72,0 \%$ na Gunda, $66,3 \%$ na Isola, $62,8 \%$ na Capella, $58,6 \%$ na Stamm-52, $57,0 \%$ na Oda, $52,8 \%$ na Olímpia, $47,6 \%$ na Delta A e $44,6 \%$ na Patrones. A redução média entre as 9 variedades foi de $60,8 \%$.

A redução em número de tubérculos na planta afetada foi de $42,3 \%$ na Aquila, $37,6 \%$ na Stamm-52, $31,7 \%$ na Olímipa, $29,4 \%$ na Gunda, $27,7 \%$ na Isola, $18,6 \%$ na Capella, $14,2 \%$ na Delta $\mathrm{A}$ e $6,7 \%$ na Oda. Sòmente a variedade Patrones revelou aumento do número de tubérculos $(13,5 \%)$. A redução média em número de tubérculos foi de $23,3 \%$ na planta afetada.

\section{2 - REDUÇão NA PRODUÇÃO DE TUBÉRCULOS GRAÚdOS PELA PLANTA AFETADA}

Houve grande redução na produção de tubérculos tipo "especial" (acima de $50 \mathrm{~mm}$ ) nas plantas afetadas de tôdas as variedades, como se vê no quadro 2. Nas 6 variedades em que foram tomados os pesos dos tubérculos após classificados, observa-se que essa redução foi de $74,1 \%$ na Delta $A$ até $97,1 \%$ na Gunda, dando uma redução média de $89,7 \%$. Paralelamente, o número de tubérculos dessa categoria na planta afetada foi reduzido de $70,6 \%$ na Delta $A$ até $100,0 \%$ na Aquila, o que dá uma média de $85,9 \%$ de redução.

A redução na produção de tubérculos tipo "primeira" (40-50 $\mathrm{mm}$ ) da planta afetada, excetuando a variedade Delta A, variou de $24,8 \%$ a $73,9 \%$ em pêso e de $18,1 \%$ a $74,0 \%$ em número de tubérculos. Na variedade Delta $\mathrm{A}$ houve aumento do tipo "primeira", na produção da planta afetada, em 7,0\% (pêso dos tubérculos) e 5,9\% (número de tubérculos). A redução média, nessa categoria, entre as 9 variedades, foi de $51,3 \%$ em pêso e de $53,2 \%$ em número de tubérculos.

\section{3 - AUMENTO NA PRODUÇÃO DE TUBÉRCULOS MÉDIOS E MIÚDOS DA PLANTA AFETADA}

De modo geral, houve aumento na produção de tubérculos médios (tipos "segunda" e "terceira") e miúdos (tipo "quarta") das plantas afetadas em relação às sadias.

No tipo "segunda", houve aumento em 5 variedades (Capella, Oda, Olímpia, Delta A e Patrones) das 9 usadas, variando de $36,4 \%$ a $63,9 \%$ em pêso e de $4,6 \%$ a $52,3 \%$ em número de tubérculos. Nas 4 restantes (Aquila, Gunda, Stamm-52 e Isola) 
houve diminuição na produção de tubérculos tipo "segunda" pela planta afetada, variando de $8,8 \%$ a $35,0 \%$ em pêso e de $4,4 \%$ a $58,9 \%$ em número de tubérculos. O aumento médio percentual, entre as 9 variedades, em pêso e número de tubérculos dessa categoria foi de $13,9 \%$ e $4,2 \%$, respectivamente.

Nos tipos "terceira" e "quarta", a maioria das variedades apresentou aumento em pêso e número de tubérculos produzidos pela planta afetada em relação à sadia. Sòmente a Stamm-52 é que apresentou redução na produção dos referidos tipos pela planta afetada.

\section{4 - DISCUSSÃO E CONCLUSÓES}

A determinação das perdas causadas na produção da batata por vírus perpetuáveis através dos tubérculos, em condiçōes de campo, como a descrita no presente trabalho, é considerada a mais apropriada. As avaliações feitas no campo se aproximam mais da realidade do que as feitas com plantas em vasos, onde encontram limitação para seu máximo desenvolvimento. Todavia, alguns aspectos devem ser analisados.

O primeiro aspecto a ser considerado é o da proximidade entre planta sadia e afetada. Se a planta sadia fôr marcada exatamente ao lado da afetada, poderá haver certo efeito favorável à sadia, em vista da falta de desenvolvimento da planta afetada. Contudo, êsse aspecto foi considerado, tendo-se marcado sempre como sadia a segunda planta sem sintoma adjacente à afetada.

Outro fator que poderia influir nas determinações seria a infecção tardia, não identificada através de inspeção visual, nas plantas marcadas como sadias, o que viria interferir nos valores das produções atribuídas a essas plantas. Isso pode ter acontecido realmente, em vista da ausência de sintomas durante o ciclo. Contudo, se a perda causada por êsse tipo de infecção pelo enrolamento fôsse mensurável, isso viria aumentar ainda mais a diferença entre a produção de plantas sadias e afetadas.

O pressnte trabalho mostra que o enrolamento da fôlha é uma moléstia que causa graves prejuízos na produção da batata no Estado de São Paulo. Os dados obtidos com 9 diferentes variedades largamente cultivadas no Estado mostram que a redução média causada por essa moléstia na produção da planta 
com sintoma de enrolamento secundário é de 60,8\%. Ao se proceder à classificação dos tubérculos em tipos comerciais, observou-se que essa redução é mais acentuada ainda nos tipos graúdos de "especial" e "primeira", nos quais atinge $89,7 \%$ e $51,3 \%$, respectivamente, de redução média entre as 9 varidades. Se juntarmos os pêsos dos tubérculos tipo "especial" e "primeira", teremos uma redução média de $75,5 \%$ na produção de graúdos pela planta afetada.

Se levarmos em consideração que os tubérculos médios ("segunda" e "terceira") e miúdos ("quarta") somados representam nuito pouco em pêso e que sua cotação no mercado para consumo de mesa é, normalmente, muito baixa, pode-se considerar como sendo de $75 \%$ o valor médio de redução ocasionada pelo enrolamento secundário na produção da planta afetada.

Isso dá uma redução de $0,75 \%$ para cada $1,0 \%$ de enrolamento na batata-semente plantada. Portanto, numa lavoura com $30 \%$ de enrolamento secundário, que é o minimo esperado quando - lavrador usa "semente comum", a redução na produção seria de $22,5 \%$ em relação a um batatal, de mesma variedade e em iguais condições, isento de vírus. Analisando-se sob outro ângulo, o lavrador que usa "semente comum" e passa a plantar batata-semente isenta de vírus conseguirá um aumento de 29\% em relação à situação anterior. O lucro obtido com o uso dessa boa batata-semente estaria em função do seu custo, do rendimento obtido e do preço alcançado no mercado pela safra.

Com base nos elementos fornecidos pelas determinações aqui descritas, podemos considerar que, para cada $1 \%$ de virus na semente, há uma redução de $0,75 \%$ na produção. Portanto, uma batata-semente que tivesse $10 \%$ de vírus a menos que a "semente comum" poderia dar, em condições médias, um acréscimo de mais de 60 sacos por alqueire. Isso equivale a dizer que o uso de uma batata-semente que tenha até um máximo de $20 \%$ de virus do enrolamento e custe $50 \%$ a mais que a "semente comum" (com um mínimo de $30 \%$ de enrolamento) ainda assim ofereceria acréscimo compensador na produção.

Há vantagens adicionais com o emprêgo de batata-semente de baixo teor de virus, tais como a menor possibilidade dêsses batatais servirem de fonte de virus para outras plantações da mesma cultura ou de outras suscetíveis ao virus. 
F. P. CUPERTINO \& A. S. COSTA

Pelo número e distribuição dos tubérculos produzidos pelas plantas sadias e afetadas, como se vê pelo quadro 1 , pode-se dizer que o plantio de tubérculos graúdos oferece maior possibilidade de obtenção de plantas sadias, a partir de "semente comum", porque as plantas doentes tiveram grandemente reduzida sua produção de tubérculos dessa categoria.

EVALUATION OF YIELD LOSSES INDUCED BY POTATO LEAF ROLL

\section{SUMMARY}

A comparison of 50 pairs of field healthy and leaf roll infected potato plants of nine varieties indicated that the total yield reduction was on the average 60.7 per cent. Yield reduction of the two largest and most marketable potato sizes ("especial" and "primeira") reached 75.6 per cent. Aquila and Gunda had the highest yield losses (73.4 and 72.0 per cent); Delta $A$ and Patrones had the lowest ( 47.6 and 44.6 per cent). Reduction in the yield of the larger tuber sizes was generally greater than total losses.

\section{LITERATURA CITADA}

1. CUPERTINO, F. P. \& COSTA, A. S. Enrolamento apical da batata, sintomas da estação corrente do vírus do enrolamento. Revista da Sociedade Brasileira de Fitopatologia, 2:75-80, 1968. 